\title{
POTENSI AIR TANAH DI DAERAH CIKARANG DAN SEKITARNYA, KABUPATEN BEKASI BERDASARKAN ANALISIS PENGUKURAN GEOLISTRIK
}

\author{
Oleh : \\ Heru Sri Naryanto \\ Peneliti di Pusat Teknologi Sumberdaya Lahan, Wilayah dan Mitigasi Bencana (PTLWB)-BPPT
}

\begin{abstract}
Groundwater is one of the most important for human activities. The effects of land use and population changes in Bekasi area cause the degradation of groundwater quantity and quality. The aquifers potential in Cikarang and its surrounding as a study area are studied using geoelectric method. Geoelectric analysis can be measured the geometry of subsurface aquifer (thickness, depth, distribution, and structural geology). The aquifers in the study area are included of Bekasi Groundwater Basin System. The aquifers contain confined aquifer and unconfined aquifer. The thickness of unconfined aquifers less than $30 \mathrm{~m}$, as lenses and bottom depth less than $40 \mathrm{~m}$ below of land surface. The thickness of confined aquifers is variation with maximum $80 \mathrm{~m}$ and the bottom depth 20-160 m below of land surface. The degradation of groundwater in Cikarang and its surrounding needs better groundwater management for sustainable development.
\end{abstract}

Katakunci : potensi airtanah, akuifer, geolistrik, Cikarang

\section{LATAR BELAKANG}

Airtanah merupakan salah satu sumber daya air yang sangat penting dalam mencukupi kebutuhan manusia, baik untuk kebutuhan domestik maupun industri. Jika dibandingkan dengan sumber air bersih lainnya, maka airtanah mempunyai nilai ekonomis yang lebih tinggi karena biaya produksi yang rendah dan kualitas lebih baik. Meskipun demikian airtanah mempunyai kuantitas yang terbatas, karena tergantung pada geometri atau bentuk dan sebaran akuifernya. Pemanfaatan airtanah dengan cara pembuatan sumur, baik sumur gali atau sumur bor, kondisi hidrogeologi di bawah permukaan akan memberikan respon yang ditunjukkan oleh perubahan-perubahan kuantitas maupun kualitas airtanahnya.

Keberadaan airtanah harus dilpertahankan yang berarti asas manfaat, keseimbangan dan kelestarian dalam pengelolaan sumberdaya tersebut tetap dapat terpenuhi. Airtanah adalah komoditi ekonomi yang berperan vital, bahkan di beberapa daerah peran tersebut dapat digolongkan sebagai faktor strategis. Namun di pihak lain, pemanfaatan airtanah telah menimbulkan dampak negatif berupa penurunan kuantitas dan kualitas sumberdaya tersebut serta lingkungan sekitarnya.

Informasi bawah permukaan merupakan salah satu komponen penting dalam melakukan kegiatan yang berkaitan dengan bumi. Informasi ini meliputi struktur geologi (lipatan, patahan, rekahan), jenis dan sifat fisis batuan, susunan batuan di bawah permukaan, kedalaman, ketebalan dan distribusinya, termasuk kondisi akuifer pengandung airtanah. Salah satu cara untuk bisa mengetahui kondisi bawah permukaan tersebut adalah melakukan pengukuran geofisika dengan metode geolistrik 2D (resistivity 2D).

Pada saat ini kondisi pengambilan airtanah di Kabupaten Bekasi telah sampai suatu kondisi yang melebihi batas keseimbangan antara pasokan airtanah dengan jumlah pengambilan. Dampak negatif terhadap kondisi airtanah terlihat dari terus menurunnya muka airtanah, kuantitas maupun kualitasnya. Memperhatikan kondisi demikian perlu kiranya mengetahui potensi airtanah dengan baik di Kabupaten Bekasi untuk bisa dilakukan pengelolaan airtanah secara terpadu berkesinambungan.

Pengukuran geolistrik 2D telah dilakukan di daerah Bekasi untuk mengetahui potensi airtanah dalam akuifer yang mengandungnya. Lokasi studi berada di daerah Cikarang dan sekitarnya, Kabupaten Bekasi Provinsi Jawa Barat, khususnya di kecamatan-kecamatan Tambun Selatan, Cibitung, Cikarang Barat, Cikarang Utara, Cikarang Timur dan Kedung Waringin.

\section{DASAR PEMIKIRAN / HIPOTESIS}

Pertumbuhan industri disertai pertumbuhan penduduk yang sangat pesat, maka kebutuhan air juga meningkat sehingga pemanfaatan airtanah saat ini maupun ke depan sudah tidak dapat dihindari lagi. Pemanfatan lahan untuk berbagai peruntukan kawasan industri, perumahan, buangan limbah cair/padat, 
penambangan, pertanian, transportasi, penyediaan prasarana air dan lain-lain, akan mempengaruhi kuantitas dan kualitas airtanah.

Eksplorasi dan eksploitasi airtanah untuk memenuhi kebutuhan domestik dan industri, perlu diketahui struktur atau geometri lapisan pembawa air (akuifer tidak tertekan/bebas atau tertekan) di bawah permukaan. Geometri akuifer ditetapkan berdasarkan analisis litologi dan struktur bawah permukaan, sehingga dapat ditentukan litologi yang berperan sebagai akuifer atau nonakuifer (akuitar, akuiklud, atau akuifug).

Pengukuran geolistrik 2D merupakan salah satu pekerjaan metode geolistrik yang dilakukan untuk mengetahui informasi bawah permukaan, yang antara lain bisa untuk mendeteksi kondisi geometri akuifer baik ketebalan, kedalaman dan penyebarannya. Dengan demikian batas dan arah hamparan serta kontinuitas lapisan akuifer dapat diketahui secara vertikal dan horisontal. Dari pengukuran tersebut bisa didapatkan informasi mengenai cadangan airtanah, yang bisa menjadi acuan dalam pengelolaan airtanah.

\section{MAKSUD DAN TUJUAN}

Maksud dilakukannya studi adalah untuk mengetahui potensi airtanah dari konfigurasi akuifernya berdasarkan analisis pengukuran geolistrik 2D. Sedangkan tujuannya adalah untuk:

1. Menduga ketebalan, kedalaman dan penyebaran perlapisan batuan secara vertikal dan horisontal.

2. Mendapatkan informasi mengenai cadangan airtanah

3. Menduga penyebaran lapisan batuan yang berfungsi sebagai lapisan pembawa air atau akuifer.

4. Menduga daerah yang mempunyai potensi airtanah untuk dapat dikembangkan lebih lanjut.

5. Menjadi acuan bagi Pemerintah Daerah dalam pedoman kebijakan pengelolaan airtanah dan rencana pembangunan.

\section{METODOLOGI}

Metode yang dilakukan dalam studi adalah kegiatan-kegiatan yang berkaitan dengan : studi referensi, geologi, geohidrologi, pengukuran geofisika dengan metode geolistrik 2D, analisis dan interpretasi data untuk menduga ketebalan, kedalaman dan penyebaran perlapisan batuan secara vertikal dan horisontal.

\section{KONDISI GEOLOGI REGIONAL}

Morfologi regional kawasan Kabupaten Bekasi yang terletak di Jawa Barat bagian utara secara regional berada pada zona Dataran Pantai Utara (Gambar 1) (1). Secara umum kondisi morfologi daerah di bagian utara dan selatan berbeda. Morfologi Kabupaten Bekasi terdiri dari dua bagian, yaitu morfologi dataran rendah di sebagian daerah utara dan morfologi bergelombang di daerah selatan. Ketinggian rata-rata antara 6-115 meter di atas muka air laut rata-rata dengan kemiringan antara $0-25^{\circ}$. Kondisi morfologi regional secara umum adalah sebagai berikut :

1. Morfologi dataran, terletak di bagian utara yang merupakan daerah relatif datar, dibentuk oleh endapan aluvial pantai dan aluvial sungai berukuran lempung-kerakal, merupakan dataran delta, rawa, pematang pantai, aluvial, sungai, tanggul alam, dan aluvial sungai lama.

2. Morfologi perbukitan, terletak di bagian selatan yang terbentuk oleh berbagai jenis batuan sedimen berumur Kuarter Tua dan Tersier, secara setempat membentuk medan perbukitan bergelombang, sementara endapan kipas aluvial berupa bahan berukuran lempung-kerakal dengan kemiringan lereng antara $3-10 \%$ dan ketinggian antara $7-20 \mathrm{~m}$.

Geologi daerah studi disusun oleh endapan batuan sedimen dan batuan volkanik berumur Tersier hingga Resen. Blok paparan utara didominasi oleh endapan laut dangkal berumur Tersier yang berada di atas batuan skis/gneiss dan granit Pra-Tersier. Secara tidak selaras di atas batuan dasar, diendapkan secara setempat-setempat endapan batuan volkanik Formasi Jatibarang (breksi, tufa, basalt, dan andesit) berumur Eosen hingga Oligosen; Formasi Talangakar yang tersusun oleh batupasir, batulempung dengan sisipan batubara dan batugamping; Formasi Baturaja yang tersusun atas batugamping bioklastik berumur Miosen Bawah; Formasi Kelapanunggal yang tersusun atas batugamping terumbu, batugamping bioklastik, napal dan kalkarenit berumur Miosen Tengah; dan Formasi Jatiluhur diendapkan secara selaras di atas Formasi Kelapanunggal, tersusun oleh batulempung / serpih abu-abu kehijauan, sisipan batupasir berumur Miosen Atas ${ }^{(5)}$. 

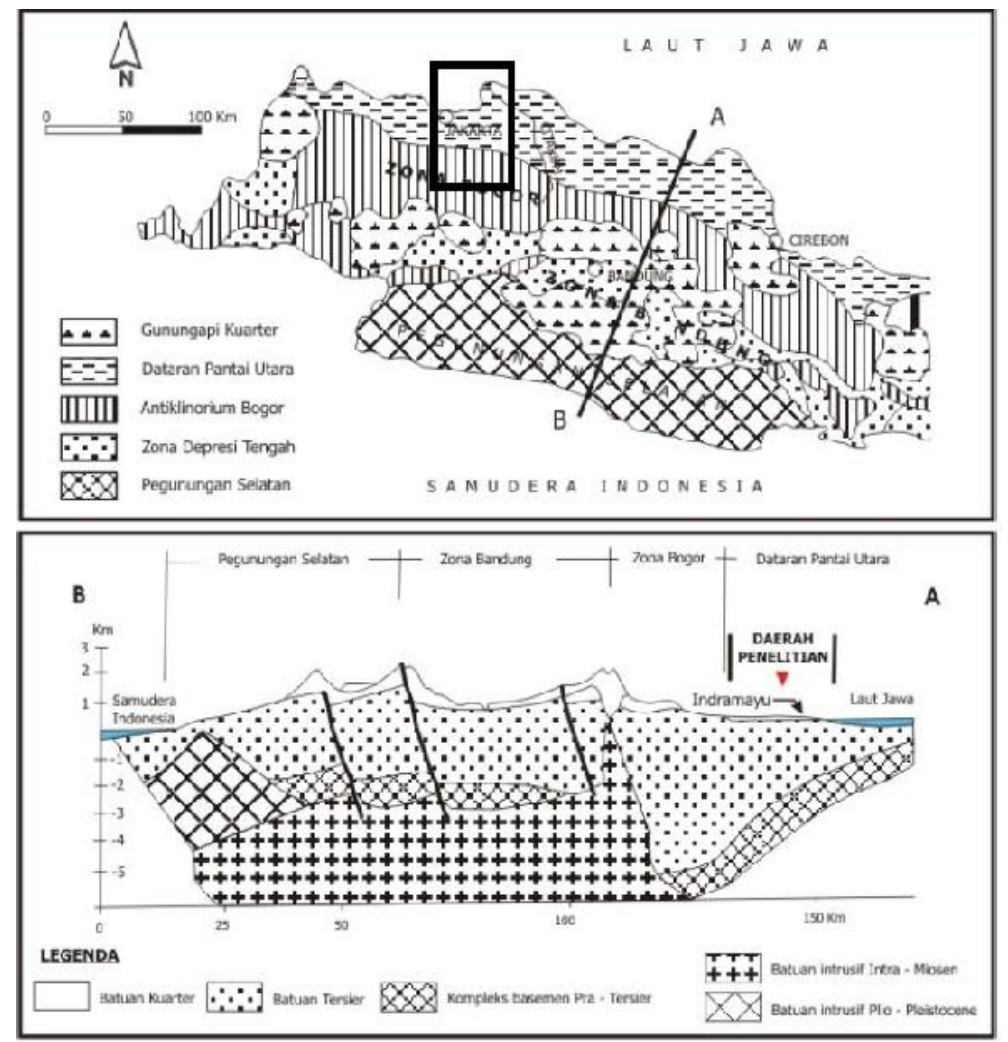

Gambar 1. Pembagian Morfologi Regional Jawa Bagian Barat Termasuk Kabupaten Bekasi (Sumber : Bemmelen 1949)

Secara tidak selaras di atas batulempung Formasi Jatiluhur terdapat Formasi Kaliwangu dengan perubahan secara berangsur. Formasi ini dicirikan oleh batulempung kehijauan yang mengandung fosil Moluska dan batupasir glokonitan. $\mathrm{Di}$ atas Formasi Kaliwangu diendapkan Formasi Citalang yang terdiri dari konglomerat, breksi, dan batupasir. Umur kedua formasi ini diperkirakan Pliosen-Pleistosen. Satuan-satuan batuan di atas tidak tersingkap di permukaan di daerah Bekasi dan secara umum merupakan batuan dasar (basement) untuk pengendapan satuan-satuan batuan yang lebih muda umurnya.

\section{KONDISI GEOHIDROLOGI}

Terdapat tiga buah sungai utama di daerah Kabupaten Bekasi, yaitu Kali Cikarang, Kali Cibeet, dan Kali Bekasi. Sungai lainnya yaitu Kali Cimanuk berada di pinggir timur daerah kabupaten dan merupakan batas dengan daerah Kabupaten Krawang. Sungai-sungai bersifat sub paralel dengan aliran berarah timur laut dan barat laut. Aliran sungai-sungai tersebut berasal dari kawasan gunungapi di bagian selatan di sekitar G. Pangrango. Kawasan selatan Kabupaten Bekasi tersebut merupakan daerah tangkapan hujan (catchment area) bagi daerah aliran sungai yang mengalir ke daerah ini. Aliran sungai yang melewati lapisan batuan bersifat permeabel terhadap air pada zona kipas aluvial volkanik gunungapi tersebut memberikan resapan yang baik untuk akuifer-akuifer pada lapisan aluvial tersebut. Di bagian hilir yang berada pada dataran pantai dengan batuan yang bersifat impermeabel seperti lempung, resapanresapan air sungai ke dalam akuifer akan berjumlah lebih kecil (3).

\subsection{Cekungan Air Tanah}

Berdasarkan hasil inventarisasi potensi airtanah seluruh Indonesia, Kabupaten Bekasi berada pada sistem Cekungan Airtanah Jakarta dan Cekungan Airtanah Krawang-Jatibarang (2). Batas kedua cekungan airtanah tersebut adalah Kali Bekasi yang didefinisikan sebagai batas aliran tetap (Gambar 2). Bagian alas (basement) dari cekungan airtanah terbentuk oleh endapan sedimen Tersier yang terdiri dari batulempung, napal, dan batugamping dari Formasi Jatiluhur dan Formasi Klapanunggal yang telah mengalami proses pematahan dan perlipatan. Formasi batuan berumur Tersier ini bersifat impermeabel atau kedap air karena telah mengalami kompaksi oleh tekanan gaya tektonik yang menyebabkan terbentuknya struktur patahan dan lipatan. 


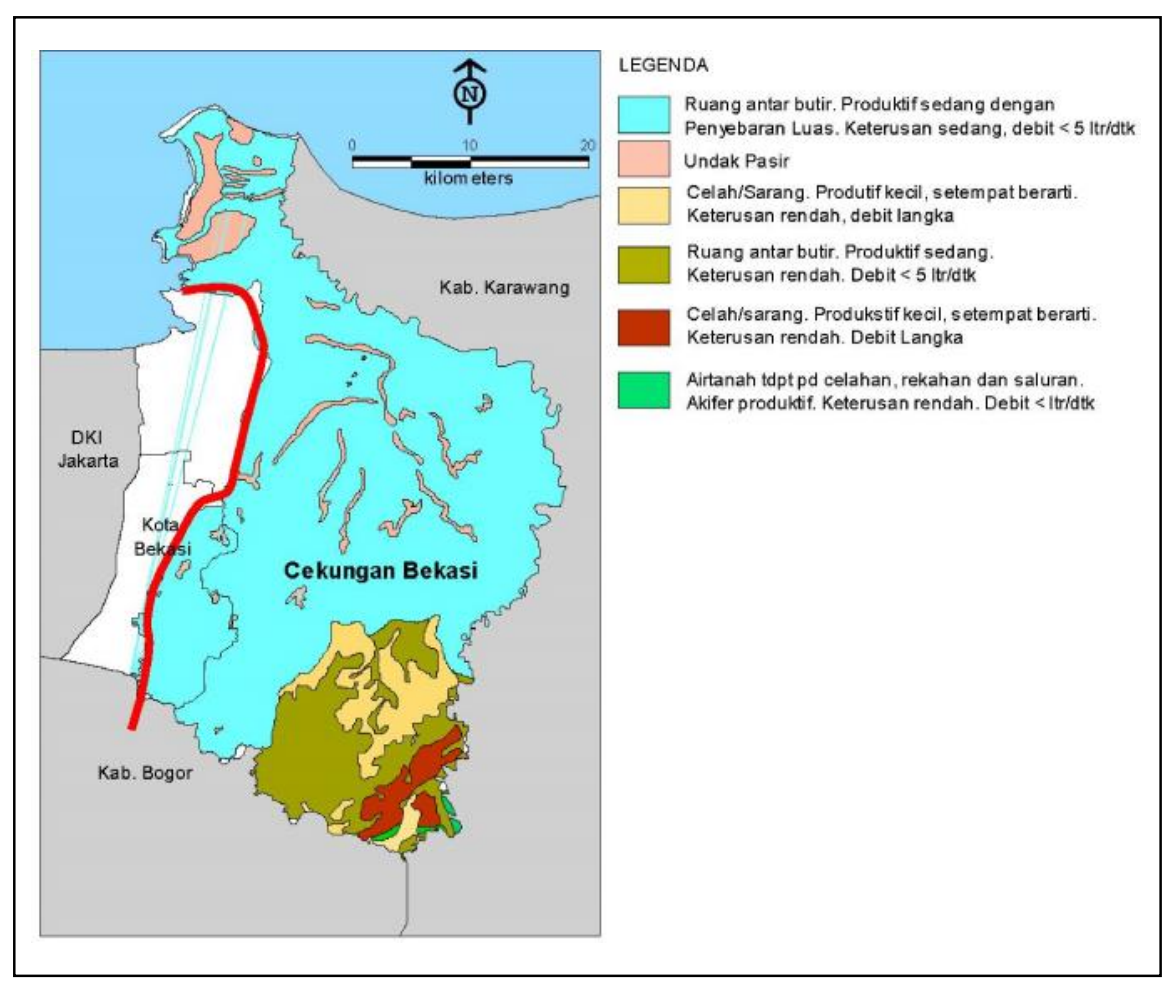

Gambar 2. Cekungan Airtanah Bekasi Yang Berbatasan Dengan Cekungan Airtanah Jakarta Di Bagian Baratnya (Sumber : DGTL, 1993)

\subsection{Sistem Akuifer}

Hidrogeologi regional daerah studi menunjukkan adanya tiga sistem akuifer, yaitu:

1. Sistem akuifer Endapan Aluvial Sungai/Pantai.

\section{Sistem Akuifer Endapan Gunungapi (volkanik).}

\section{Sistem Akuifer Sedimen Tersier.}

Data-data pemboran diperlukan untuk dapat menggambarkan lapisan akuifer dan lapisan kedap air yang ada pada suatu daerah. Data-data tersebut akan dikorelasi untuk mengetahui distribusi ketebalan dan pelamparan akuifer, serta basement akuifer. Rekonstruksi hidrogeologi berdasarkan data-data pemboran airtanah, seperti tampak pada Gambar 3 yang memperlihatkan sistem akuifer di daerah Bekasi mempunyai kemiringan ke arah utara ${ }^{(4)}$.

$$
\text { Lapisan-lapisan batupasir }
$$

dan konglomerat merupakan penyusun akuifer tidak tertekan (bebas) dan akuifer semi tertekan (semi confined aquifer). Lapisan batulempung dan batulanau berperan sebagai lapisan penekan yang bersifat akuiklud dan akuitar. Bentuk lapisan akuifer ini adalah berupa kanal-kanal (channel) yang terbentuk oleh sungai purba yang berfungsi sebagai media tranportasi dan sedimentasi endapan batuan sedimen.

\section{PENGUKURAN GEOLISTRIK}

Pengukuran geolistrik bertujuan untuk mengetahui kondisi bawah permukaan. Metode geolistrik merupakan salah satu metode geofisika yang sering digunakan untuk tujuan eksplorasi airtanah khususnya untuk menentukan lapisan pembawa air (akuifer). Dengan menggunakan metode ini diharapkan dapat diketahui susunan, kedalaman dan penyebaran lapisan bawah permukaan berdasarkan harga tahanan jenis yang diperoleh. Pada metoda geolistrik, dilakukan injeksi arus ke dalam permukaan bumi. Selanjutnya respon yang diberikan bumi dicatat oleh alat yang disebut resistivitymeter. Data yang dicatat adalah nilai tahanan jenis (R) dalam satuan ohm mulai kedalaman 0 meter hingga 150 meter pada jarak 0 hingga 450 meter. Dari data yang tercatat ini kemudian dihitung sebaran nilai tahanan jenis/resistivitas (resistivity) batuan di bawah permukaan. Karena masing-masing batuan mempunyai nilai resistivity yang typical, maka dari sebaran tahanan jenis inilah kita dapat melakukan interpretasi jenis batuan, sifat batuan dan struktur geologi yag mungkin ada di bawah permukaan bumi. 


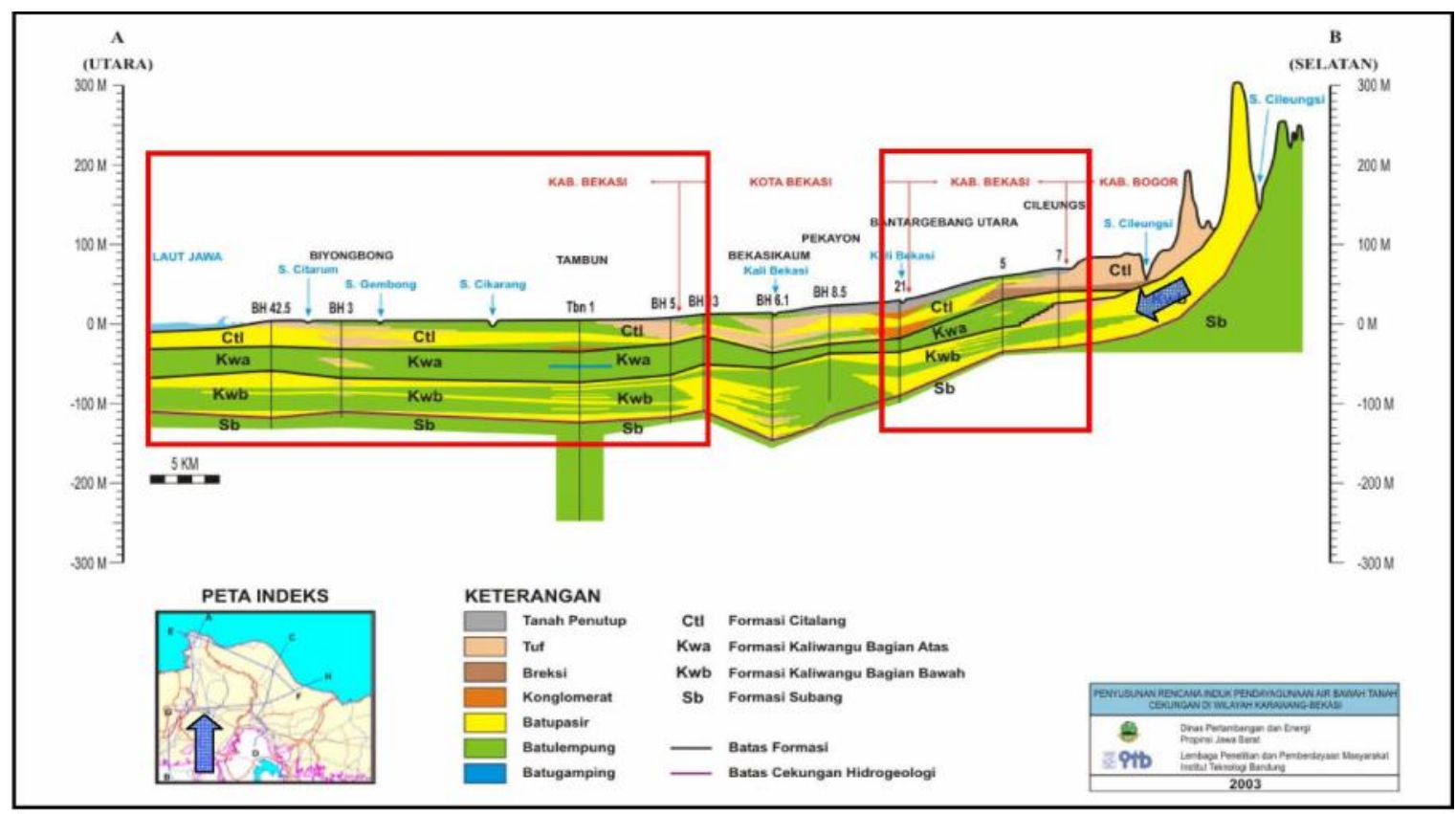

Gmbar 3. Penampang Geohidrologi Regional Berarah Utara-Selatan Daerah Bekasi Dengan Arah Aliran Airtanah Ke Utara (Sumber LPPM-ITB, 2003)

Eksplorasi dengan metode geolistrik dilakukan di atas permukaan tanah dengan menginjeksi arus searah (DC) frekuensi rendah ke dalam tanah melalui dua elektroda arus. Besar beda potensial yang terjadi diukur di permukaan dengan dua elektroda potensial. Hasil pengukuran besar yang diinjeksikan dan beda potensial yang terjadi untuk setiap jarak elektroda yang berbeda akan memberikan variasi harga tahanan jenis.

Potensial listrik didefinisikan sebagai energi potensial $(U)$ per satuan muatan uji $(Q)$, atau ekspresi matematisnya adalah :

$$
U=\int_{J_{\infty}}^{r} E \cdot d r=\begin{array}{ccc} 
& & \\
------ & - \\
4 \pi \varepsilon & r
\end{array}
$$

pada persamaan tersebut ;

$$
\begin{array}{ll}
\mathrm{U} & =\text { energi potensial } \\
\mathrm{E} & =\text { medan listrik } \\
\mathrm{Q} & =\text { gaya coloumb } \\
\pi, \varepsilon & =\text { konstanta } \\
\mathrm{r} & =\text { jarak antar muatan }
\end{array}
$$

Arus listrik adalah gerak muatan negatif (elektron) pada materi dalam proses mengatur diri menuju keseimbangan. Peristiwa ini terjadi bila materi mengalami gangguan karena adanya medan listrik. Bila medan listrik arahnya selalu tetap menuju ke satu arah, maka arus listrik yang mengalir akan tetap juga arahnya. Arus listrik yang mengalir searah disebut DC (Direct Current) sedangkan yang mengalir bolak-balik disebut AC (Alternating Current). Hubungan antara arus listrik dengan muatannya, secara matematis diekspresikan sebagai $\mathrm{I}=(\mathrm{dQ} / \mathrm{dt})$. Menurut Hukum Ohm, hubungan antara besarnya beda potensial listrik (V), kuat arus (I) dan besarnya tahanan kawat penghantar adalah $\mathrm{V}=\mathrm{R}$. I.

Pada metoda geolistrik 1D, pembahasan mengenai aliran listrik dalam bumi didasarkan pada asumsi bahwa bumi merupakan medium homogen isotropis. Lapisan batuan di bawah permukaan bumi diasumsikan berbentuk berlapis-lapis. Apabila titik arus pada pembahasan tersebut di atas terletak di permukaan bumi, maka arah arus listrik dan garis equipotensialnya dapat dilihat pada Gambar 4.

Area sebaran arah arus adalah setengah bola, sehingga permukaan luas $=2 \pi$ r. Dengan demikian persamaan menjadi :

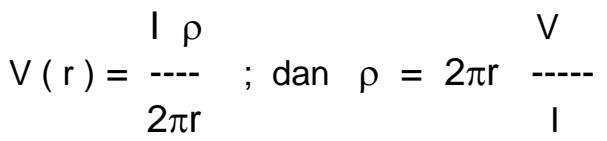

Pada survei geolistrik dipakai 2 (dua) sumber arus, dengan demikian arah arus listrik dan equipotensialnya adalah (Gambar 5). 


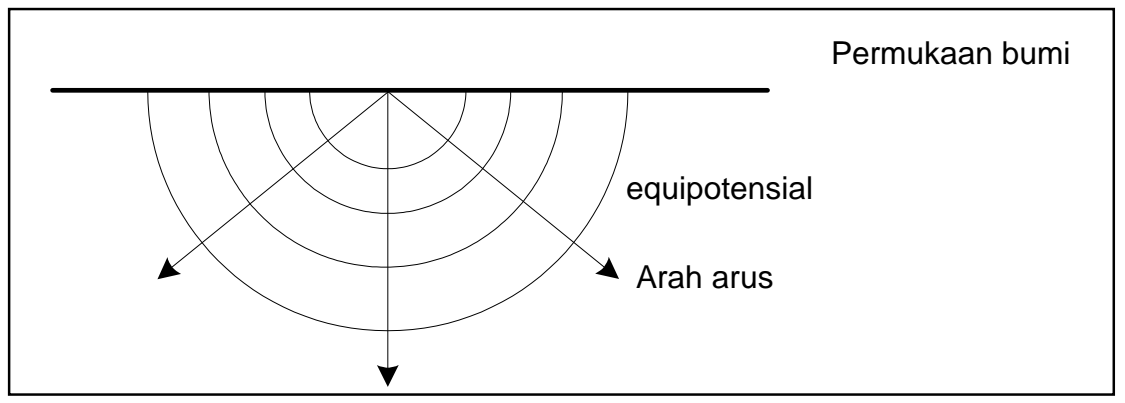

Gambar 4. Arah Arus Listrik Dan Garis Equipotensial Untuk Sumber Arus Berada Di Permukaan Bumi

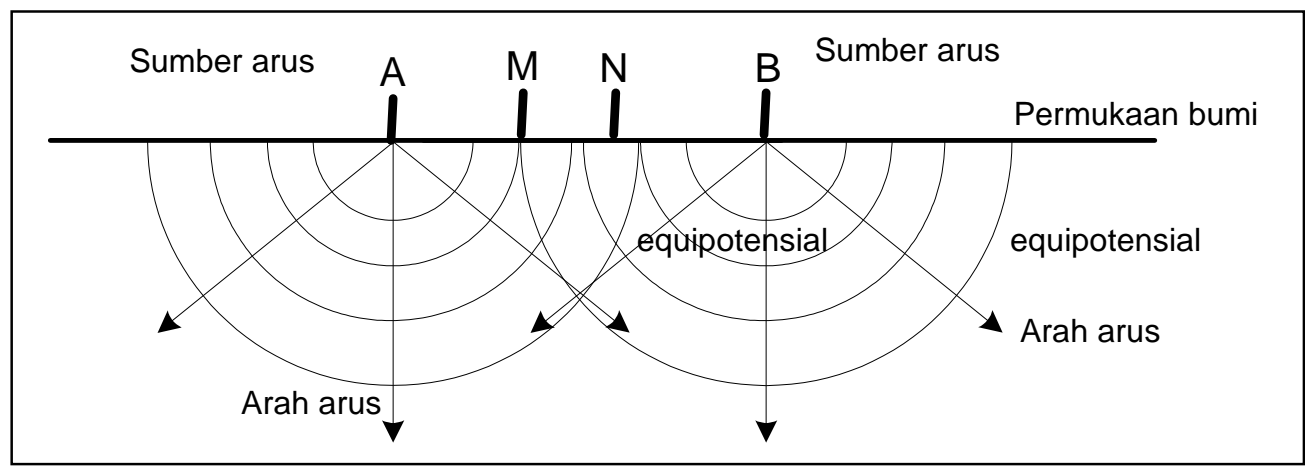

Gambar 5. Arah Arus Listrik Dan Garis Equipotensial Untuk Dua Sumber Arus Berada Di Permukaan Bumi

Pada Gambar 5, dua sumber arus digambarkan sebagai titik $A$ dan $B$, sedangkan pengukuran beda potensial dilakukan di titik M dan N. Beda potensial antara $\mathrm{MN}$ yang disebabkan arus $\mathrm{A}$ dan $\mathrm{B}$, adalah :

$$
\begin{aligned}
& \Delta \mathrm{V}=\mathrm{V}_{\mathrm{M}}-\mathrm{V}_{\mathrm{N}} \\
& =\frac{I \rho}{---}\left[\left(\begin{array}{cc}
1 & 1 \\
------- \\
\text { AM } & \text { BM }
\end{array}\right)-\left(\begin{array}{cc}
1 & 1 \\
---- & -----
\end{array}\right) \mid\right.
\end{aligned}
$$

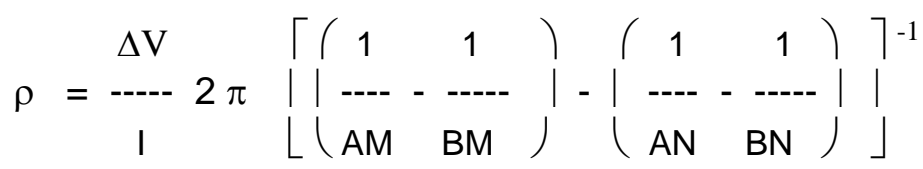

Pada persamaan ini ;

$$
\begin{aligned}
& A M=\text { jarak } A \text { ke } M ; B M=\text { jarak } B \text { ke } M \\
& A N=\text { jarak } A \text { ke } N ; B N=\text { jarak } B \text { ke } N \\
& \Delta V=\text { beda potensial, diukur di lapangan } \\
& \mathrm{I}=\text { kuat arus, diukur di lapangan } \\
& \rho \quad=\text { tahanan jenis, dihitung kemudian dipergunakan untuk interpretasi }
\end{aligned}
$$

Konfigurasi (susunan) elektroda arus dan potensial pada geolistrik 2D berbeda dengan geolistrik 1D. Pada geolistrik 2D, susunannya adalah seperti Gambar 6.

Pada pengukuran geolistrik 2D, persamaan menjadi :

$$
\begin{aligned}
& \mathrm{C} 1 \mathrm{P} 1=\mathrm{C} 2 \mathrm{P} 2=\mathrm{AM}=\mathrm{BN}=(\mathrm{n}+1) l \\
& \mathrm{C} 2 \mathrm{P} 1=\mathrm{BM}=\mathrm{n} l \\
& \mathrm{C} 1 \mathrm{P} 2=\mathrm{AN}=\sim
\end{aligned}
$$

Dengan demikian persamaan $(\mathrm{v})$ menjadi :

$$
\rho \mathrm{a}=\pi \mathrm{n}(\mathrm{n}+1) l \mathrm{R}
$$


Persamaan tersebut selanjutnya dipakai untuk mengolah data hasil pengukuran geolistrik 2D. Hasil perhitungan menggunakan persamaan tersebut baru menghasilkan nilai tahanan jenis dan kedalaman semu. Untuk mendapatkan nilai tahanan jenis dan kedalaman sebenarnya, selanjutnya dipakai pemodelan inversi 2D.

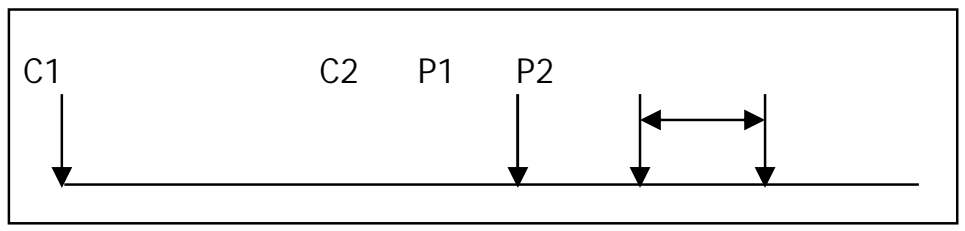

Gambar 6. Konfigurasi Elektroda Arus Dan Potensial Pada Geolistrik 2D, Sebagai Contoh Untuk Metoda Pole-Dipole. Jarak P1 $-\mathrm{P} 2$ Selalu $L \mathrm{~N} 1=$ Pengukuran Ke 1, N2 = Pengukuran Ke2, Dst.

\section{HASIL PENGUKURAN DAN ANALISIS}

Di bagian utara Kota Bekasi dan Cikarang dapat dijumpai pemboran-pemboran airtanah yang menghasilkan sumur-sumur artesis positif. Keberadaan sumur-sumur bor ini yang berada di antara Kali Bekasi dan Kali Cikarang mengindikasikan adanya suatu sistem airtanah berproduktifitas tinggi yang mengikuti alur lembah purba. Lembah-lembah purba ini telah terisi oleh material pelapukan dan erosional gunungapi di bagian selatan.

Dari data-data pemboran, berdasarkan kedalamannya maka akuifer airtanah di kawasan Bekasi dan sekitarnya (Jabodetabek) dapat dikelompokkan menjadi 3 kelompok akuifer produktif, yaitu :

1. Kelompok akuifer dengan kedalaman $<40$ $\mathrm{m}$.

2. Kelompok akuifer dengan kedalaman $40-$ $140 \mathrm{~m}$.

3. Kelompok akuifer dengan kedalaman $>140$ $\mathrm{m}$.

Pada pekerjaan survei geolistrik, telah dilakukan pengukuran sebanyak 100 titik. Lokasi pengukuran ditentukan pada daerah-daerah yang tidak mempunyai cukup data bawah permukaan, seperti di daerah-daerah yang belum terbangun, sehingga kemungkinan besar tidak tersedia data pemboran. Konfigurasi yang digunakan dalam survei adalah metode Sclumberger.

Dalam melakukan interpretasi hasil pengolahan data geolistrik banyak hal yang perlu dipertimbangkan. Karena setiap batuan memiliki nilai resistivitas yang berbeda, bergantung pada jenis mineral, densitas, porositas, temperatur, dan kandungan air di dalamnya, maka setiap proses interpretasi hasil pengolahan geolistrik, perlu dilakukan pembandingan dengan data geologi yang tersedia. Hal ini dimaksudkan untuk mempermudah dan mengurangi kesalahan dalam proses interpretasi jenis akuifer. Data geologi seperti singkapan batuan, log pemboran, logging geofisika, atau peta geologi dapat digunakan sebagai acuan atau referensi dalam interpretasi.

Pengambilan data geolistrik bertujuan untuk melihat profil bawah permukaan bumi berdasarkan sifat kelistrikan, sehingga dapat diduga struktur bawah permukaan dan kemungkinan zona akuifernya. Data-data log pemboran serta data-data geologi dan hidrogeologi yang tersedia dikompilasi dengan interpretasi data geolistrik. Pada Gambar 8, 9 dan 10 tampak penampang interpretasi nilai resistivitas secara profil pada beberapa lintasan berarah utara - selatan dan timur - barat.

Rekonstruksi geometri akuifer menunjukkan adanya lapisan akuifer tertekan (confined aquifer) yang diinterpretasikan sebagai lapisan batupasir. Lapisan akuifer tertekan tersebut mempunyai ketebalan bervariasi mencapai 80 meter dengan kedalaman bervariasi antara $20-160 \mathrm{~m}$ di bawah muka tanah setempat (bmts). Lapisan akuifer ini di batasi oleh lapisan batulempung di bagian atas dan bawahnya yang berfungsi sebagai lapisan penekan (confining layer).

Melalui rekonstruksi juga dapat dijumpai lapisan akuifer tidak tertekan (unconfined aquifer) yang berada di bawah lapisan soil. Lapisan ini tersusun oleh batupasir yang mempunyai bentuk berupa lensa. Ketebalan akuifer ini mencapai 30 meter dengan bentuk melensa sehingga ketebalannya tidak sama di semua tempat. Kedalaman batas bawah (bottom) lapisan ini mencapai $40 \mathrm{~m}$ bmts 


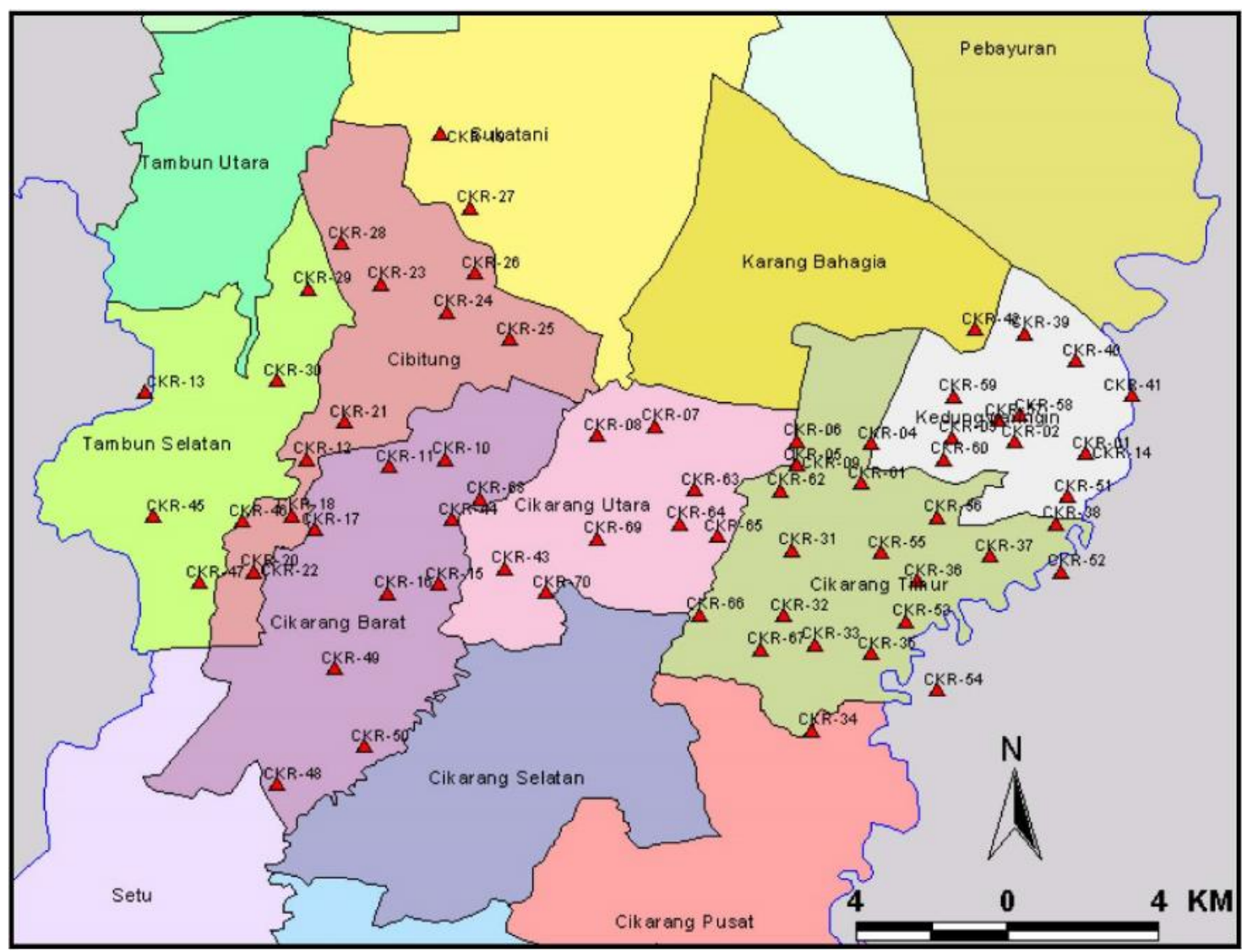

Gambar 7. Peta Lokasi Pengukuran Geolistrik

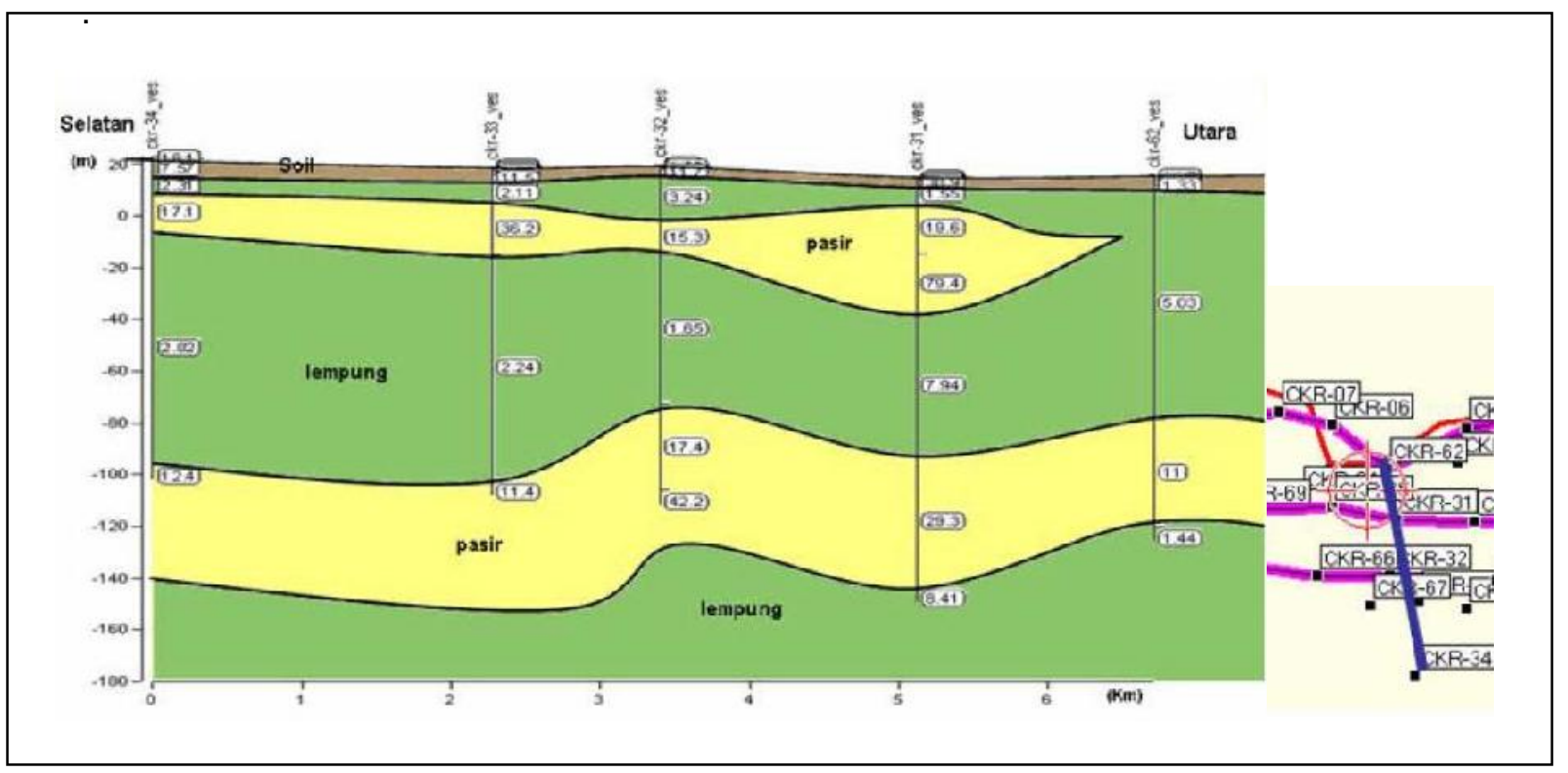

Gambar 8. Penampang Interpretasi Akuifer Profil Geolistrik Berarah Utara-Selatan (Lintasan CKR 34 Sampai CKR 62) 


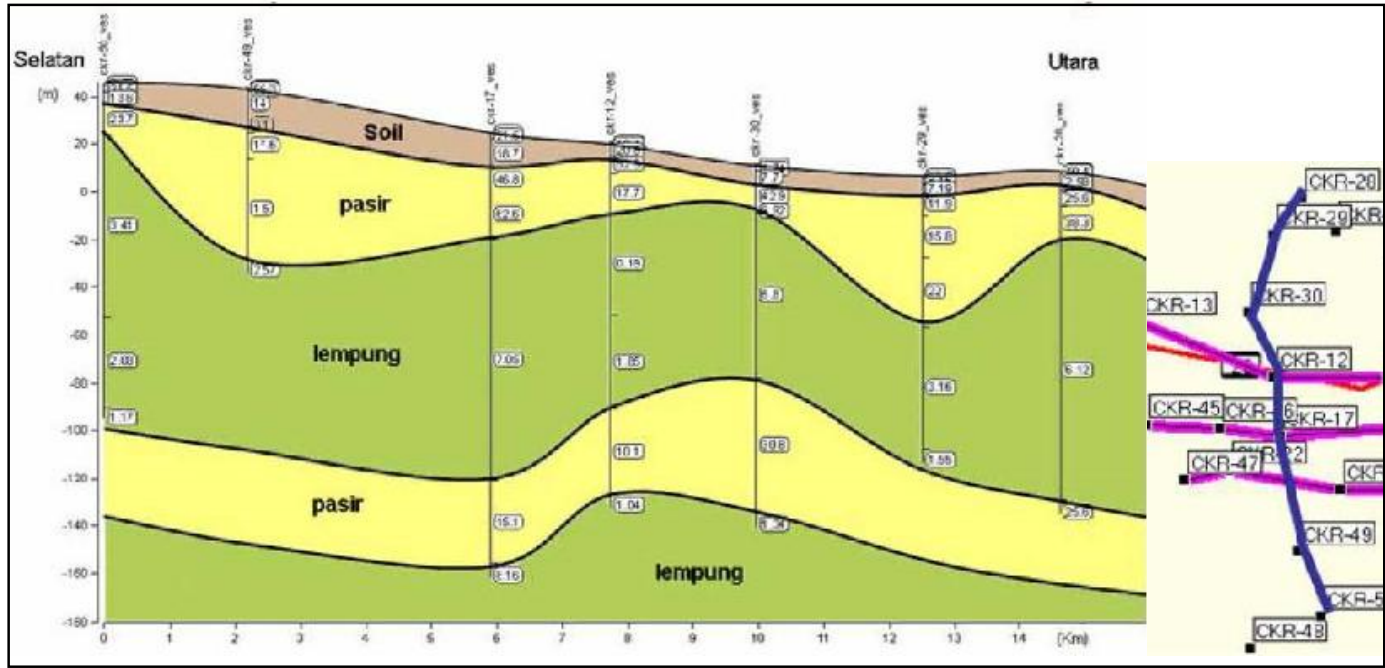

Gambar 9. Penampang Interpretasi Akuifer Profil Geolistrik Berarah Utara-Selatan (Lintasan CKR 48 Sampai CKR 28)

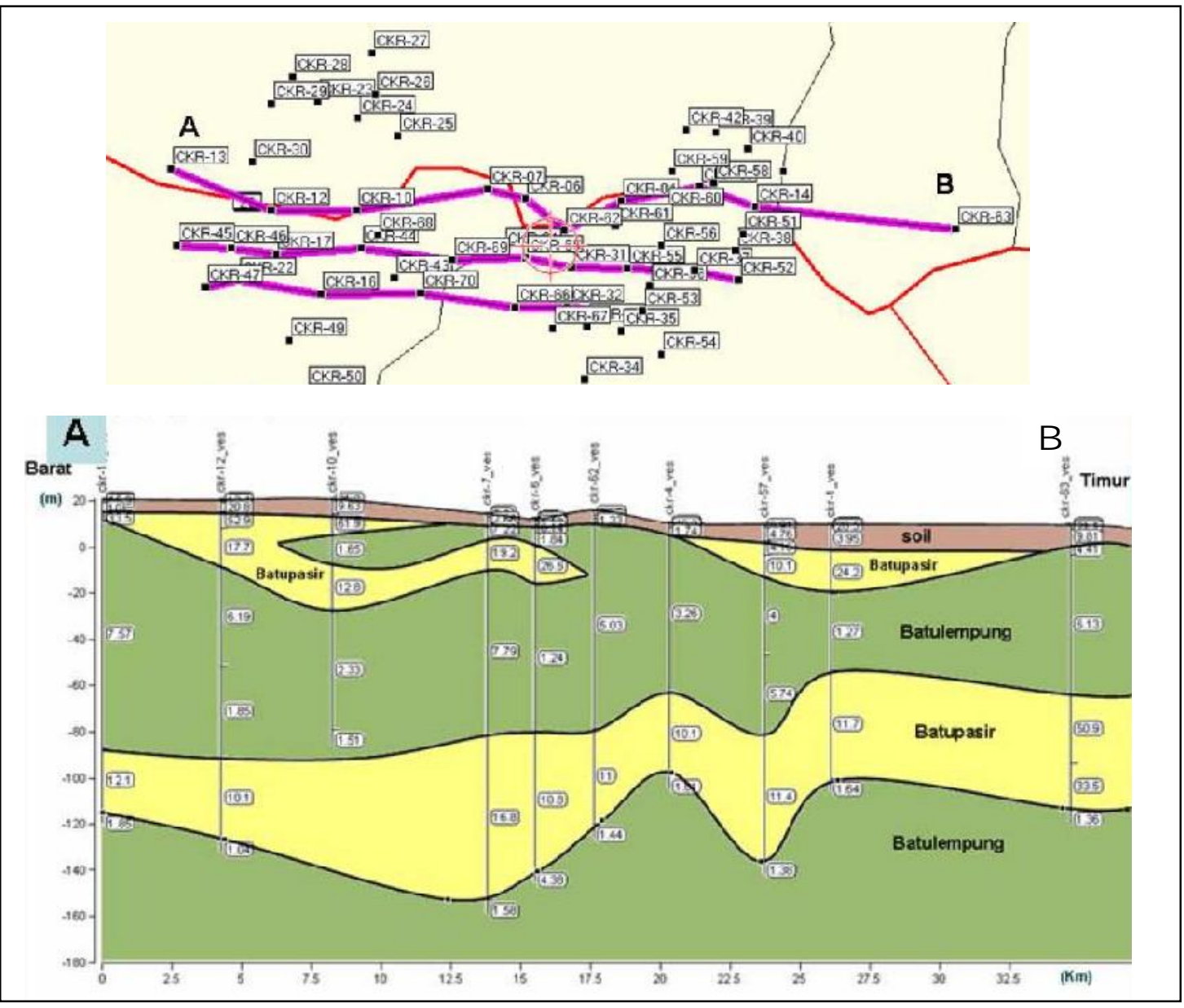

Gambar 10. Penampang Interpretasi Akuifer Profil Geolistrik Berarah Barat-Timur (lintasan A-B) 


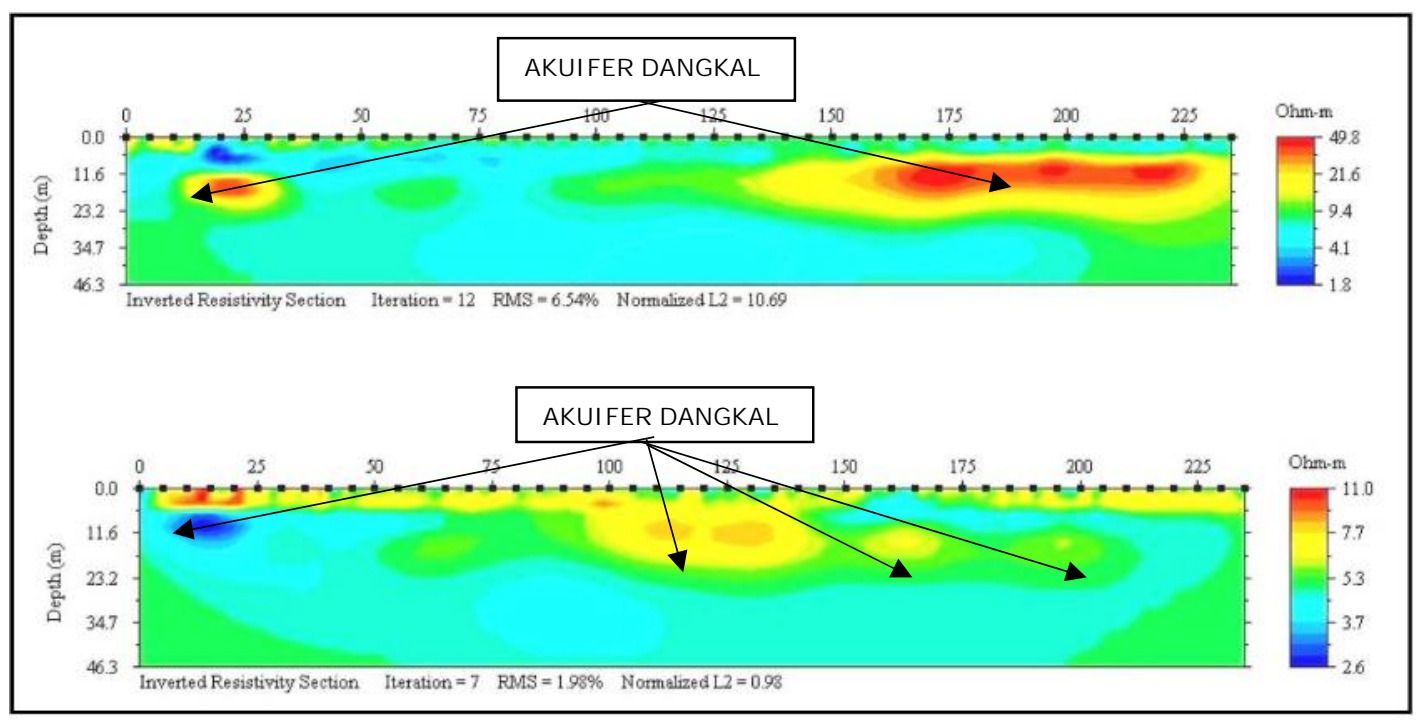

Gambar 11. Distribusi Akuifer Dangkal Yang Berbentuk Melensa Dari Hasil Analisis Geolistrik Di Daerah Kedung Waringin

Anomali resistivitas merupakan lapisan yang jenuh airtanah dan mempunyai bentuk berupa lensa-lensa. Lensa-lensa batupasir ini berada pada lapisan yang mempunyai resistivitas lebih rendah dan diperkirakan sebagai lapisan batulempung yang bersifat kedap air. Hasil rekonstruksi geometri akuifer ini menunjukkan adanya kesamaan antara litologi hasil pengukuran geolistrik dengan penampang hasil rekonstruksi log pemboran. Diperkirakan lapisan akuifer tertekan berada pada Formasi Kaliwangu, sedangkan lapisan akuifer tidak tertekan berada pada satuan batuan Formasi Citalang dan Endapan Aluvial.

Hasil interpretasi geolistrik ataupun log pemboran tidak dapat menunjukkan adanya lapisan batulanau yang berfungsi sebagai lapisan semi permeabel dan penekan pada akuifer semi tertekan. Hal ini terjadi karena dalam interpretasi data resistivitas, nilai resistivitas batulanau sulit dibedakan dengan lapisan batulempung ataupun batupasir.

Berdasarkan interpretasi tersebut, maka dapat disimpulkan bahwa di daerah studi terdapat dua (2) buah lapisan akuifer, yaitu lapisan akuifer tertekan (confined aquifer) dan lapisan akuifer tidak tertekan (unconfined aquifer). Kedalaman akuifer tertekan sangat bervariasi, namun akuifer yang berpotensi sebagai akuifer produktif berada pada kedalaman rata-rata antara $100-140 \mathrm{~m}$. Ketebalan akuifer yang mencukupi dan mempunyai penyebaran yang luas memberikan cadangan airtanah yang baik. Walaupun demikian, hal ini akan sangat dipengaruhi juga oleh jumlah resapan airtanah yang dapat masuk ke dalam akuifer.

Posisi kedalaman lapisan atas (top) akuifer dapat diinterpretasikan dari analisis nilai resistivitas. Pada Gambar 12 dan Gambar 13 telah dibuat peta elevasi top akuifer tidak tertekan dan akuifer tertekan yang dapat menunjukkan kemiringan lapisan akuifer hasil interpretasi data resistivitas. Berdasarkan data tersebut secara interpretatif, sebaran top akuifer dangkal rata-rata adalah antara $8,39 \mathrm{~m}$ sampai dengan $40,5 \mathrm{~m}$. Sedangkan sebaran top akuifer dalam rata-rata adalah antara $33,5 \mathrm{~m}$ sampai dengan $174 \mathrm{~m}$. Distribusi top akuifer tersebut memperlihatkan arah kemiringan lapisan akuifer secara regional ke arah utara dan diperkirakan aliran airtanah secara alamiah akan dikendalikan oleh kemiringan satuan batuan tersebut.

Secara alamiah masih dimungkinkan terjadi kebocoran airtanah dari akuifer tidak tertekan ke dalam akuifer tertekan di bawahnya. Namun karena ketiadaan data parameter hidraulik lapisan penyekat antara kedua akuifer tersebut, maka volume air yang mengalir sebagai kebocoran tidak dapat dihitung.

Daerah resapan (discharge) alamiah adalah berupa zona mataair dan di Kabupaten Bekasi zona ini berada di bagian luar batas selatan kabupaten dalam zona yang tidak terlalu luas pada batuan-batuan karbonat Formasi Klapanunggal yang tersingkap ke permukaan. Daerah resapan yang disebabkan oleh pengambilan airtanah oleh aktivitas manusia berada di seluruh daerah kabupaten. Namun karena batasan daerah studi, maka data-data sumur bor yang diambil dari observasi lapangan menunjukkan daerah pengambilan airtanah berada sekitar daerah-daerah di Kecamatan Tambun Selatan, Cibitung, Cikarang Barat, Cikarang Utara, Cikarang Timur. Jumlah pengambilan airtanah belum dapat diketahui karena kurangnya informasi yang didapatkan dari pengguna sumur bor (industri). 


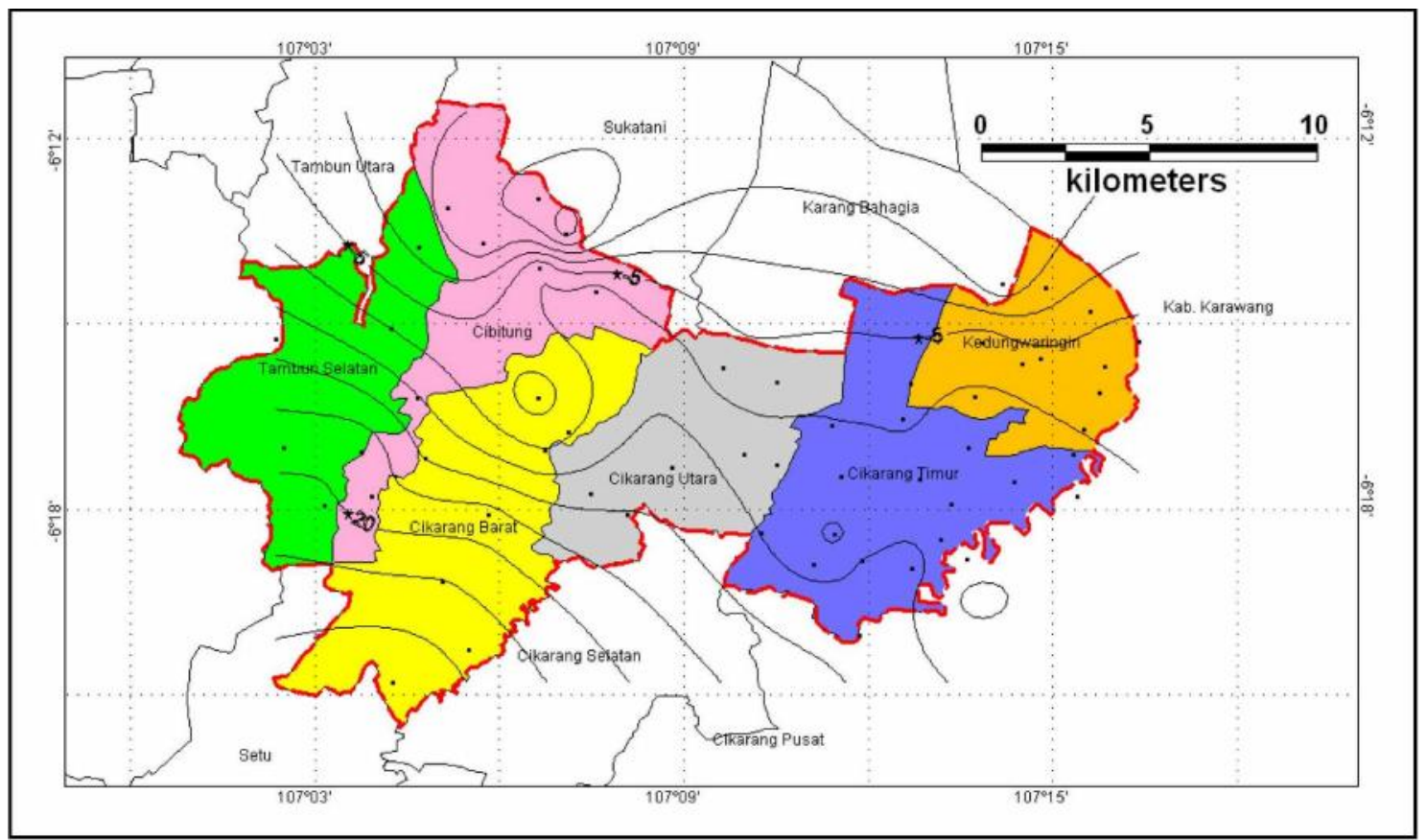

Gambar 12. Kontur Elevasi Top Akuifer Tidak Tertekan (Unconfined Aquifer) Pada Lokasi Studi

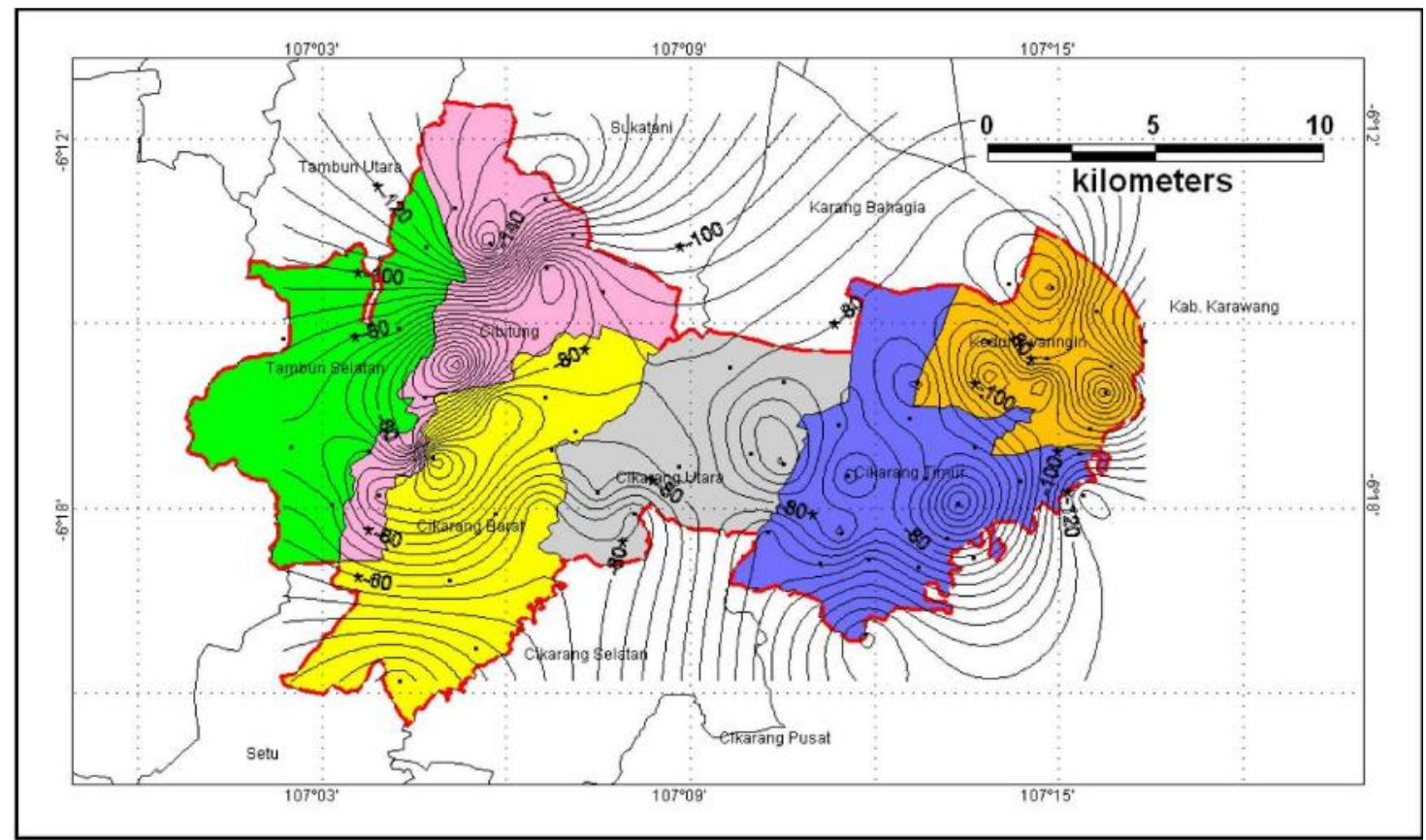

Gambar 13. Kontur Elevasi Top Akuifer Tertekan (Confined Aquifer) Pada Lokasi Studi

\section{KESIMPULAN DAN SARAN}

Dari hasil pembahasan di atas bisa disimpulkan dan disarankan sebagai berikut :

1. Morfologi Kabupaten Bekasi dibagi menjadi dua bagian, yaitu morfologi dataran rendah di sebagian daerah utara dan morfologi bergelombang di daerah selatan.

2. Geologi daerah studi disusun oleh endapan batuan sedimen dan batuan volkanik berumur Tersier hingga Resen. Blok paparan utara didominasi oleh endapan laut dangkal berumur Tersier yang berada di atas batuan skis/gneiss dan granit pra-Tersier. 
3. Airtanah yang berada di daerah Bekasi berada pada sistem Cekungan Airtanah Bekasi.

4. Hidrogeologi regional daerah studi menunjukkan adanya tiga sistem akuifer, yaitu : Sistem Akuifer Endapan Aluvial Sungai/Pantai, Sistem Akuifer Endapan Gunungapi, dan Sistem Akuifer Sedimen Tersier.

5. Lapisan-lapisan batupasir dan konglomerat merupakan penyusun akuifer tidak tertekan (bebas) dan akuifer semi tertekan. Lapisan batulempung dan batulanau berperan sebagai lapisan penekan yang bersifat akuiklud dan akuitar. Bentuk lapisan akuifer ini adalah berupa kanal-kanal yang terbentuk oleh sungai purba yang berfungsi sebagai media tranportasi dan sedimentasi endapan batuan sedimen.

6. Metode geolistrik merupakan salah satu metode geofisika yang sering digunakan untuk eksplorasi airtanah khususnya untuk menentukan kondisi bawah permukaan termasuk lapisan pembawa air (akuifer) dan lapisan kedap air, meliputi susunan, kedalaman dan penyebaran lapisan bawah permukaan berdasarkan harga tahanan jenis yang diperoleh.

7. Rekonstruksi geometri akuifer di daerah studi menunjukkan adanya lapisan akuifer tertekan yang diinterpretasikan sebagai lapisan batupasir. Lapisan akuifer tertekan tersebut mempunyai ketebalan bervariasi mencapai 80 meter dengan kedalaman bervariasi antara 20-160 m di bawah muka tanah setempat (bmts). Lapisan akuifer tidak tertekan berada di bawah lapisan soil yang tersusun oleh batupasir. Ketebalan akuifer ini mencapai 30 meter dengan bentuk melensa sehingga ketebalannya tidak sama di semua tempat. Kedalaman batas bawah lapisan ini mencapai $40 \mathrm{~m}$ bmts.

8. Sebaran top akuifer dangkal rata-rata adalah antara 8,39 m sampai dengan 40,5 m. Sedangkan sebaran top akuifer dalam ratarata adalah antara $33,5 \mathrm{~m}$ sampai dengan $174 \mathrm{~m}$. Distribusi top akuifer tersebut memperlihatkan arah kemiringan lapisan akuifer secara regional ke arah utara dan diperkirakan aliran airtanah secara alamiah akan dikendalikan oleh kemiringan satuan batuan tersebut.

9. Konservasi airtanah berkelanjutan sangat diperlukan, sehingga pemanfaatan airtanah perlu diperketat dalam hal perijinan terutama pada akuifer dalam yang digunakan untuk industri, perkantoran dan sebagainya supaya keseimbangan antara input dan output airtanah masih terjaga.

\section{DAFTAR PUSTAKA}

1. Bemmelen, R.V., 1949, The Geology of Indonesia, Government Printing, The Haque.

2. DGTL, 1993, Peta Cekungan Airtanah Bekasi, Bandung

3. Dinas Pengendalian Dampak Lingkungan dan Pertambangan (DPDLP) - Kab. Bekasi, 2006, Inventarisasi Sumberdaya Airtanah dan Kajian Batas Kawasan Lindung Airtanah di Kabupaten Bekasi, Laporan, tidak diterbitkan

4. LPPM-ITB - Distamben Propinsi Jabar, 2003, Penyusunan Rencana Induk Pendayagunaan Air Bawah Tanah di Wilayah Cekungan Karawang-Bekasi, Laporan, tidak diterbitkan

5. Martodjojo, S., 1982, Evolusi Cekungan Bogor, Jawa Barat, Disertasi Doktor GeologiITB, Bandung, tidak diterbitkan

6. Naryanto, 2000, Potensi dan Konservasi Airtanah di Cekungan Bandung, Jurnal Alami Vol. 5, No. 1, tahun 2000.

7. Soekardi, 1986, Hydrogeological Map of Indonesia, Sheet Jakarta (Jawa), DGTL, Bandung

\section{UCAPAN TERIMA KASIH}

Penulis mengucapkan banyak terima kasih kepada Ir. Agus Kuswanto, MT dan Nurhidayat, ST, MSi atas kerjasama dan segala bantuannya dalam studi ini. 